\title{
Influence of Patient Experience and Hospital Image on Patient Loyalty in Meloy Public Hospital of Sangatta, East Kutai Regency
}

\author{
Asmaryadi Asmaryadi ${ }^{1}$, Syahrir A. Pasinringi ${ }^{1 *}$, Yahya Thamrin ${ }^{2}$, Masyitha Muis ${ }^{2}$ \\ ${ }^{1}$ Department of Hospital Management, Faculty of Public Health, Hasanuddin University, Makassar, Indonesia; ${ }^{2}$ Department of \\ Occupational Health and Safety, Faculty of Public Health, Hasanuddin University, Makassar, Indonesia
}

\begin{abstract}
Edited by: Mirko Spirosk Citation: Asmaryadi A, Pasinringi SA, Thamrin Y, Muis M. Influence of Patient Experience and Hospital Image on Patient Loyalty in Meloy Public Hospital of Sangatta, Eas Kutai Regency. Open Access Maced J Med Sci. 2020 Sep 25; 8(T2): $147-15$ https://doi.org/10.3889/oamjms.2020.5213 Keywords: Patient experience; Hospital image Patient satisfaction; Patient loyalty; Hospita Correspondence: Syahrir A. Pasinringi, Departmen f Hospital Management, Faculty of Public Health, E-mail: syahrir65@yahoo.com Received: 09-Jul-2020 Revised: $11-\mathrm{Sep}-2020$ Accepted: 15-Sep-2020 Copyright: ๑ 2020 Asmaryadi Asmaryadi, Syahrir A. Pasinningi, Yahya Thamrin, Masyitha Muis Funding: This research did not receive any financial Competing Interests: The authors have declared support. competing interests exist. competing interests exist Open Access: This is an open-access anticle distributed onCommercial 4.0 International License (CC BY-NC 4.0)

BACKGROUND: Patient experience is an indicator in measuring the quality of service by placing patients as the center of service in the hospital.

AIM: This study aimed to analyze the effect of patient experience and hospital image on patient loyalty, as well as the influence of patient experience and hospital image on patient loyalty through patient satisfaction variables in Meloy Public Hospital of Sangatta.

METHODS: The design of this study was analytic observational design with cross-sectional study approach. This research was conducted at Meloy Public Hospital of Sangatta, East Kutai Regency since May to July 2019. The sample of this study was 110 respondents. The samples were taken in each treatment class at hospital by proportiona stratified random sampling. In this study we used a questionnaire and univariate, bivariate, and multivariate analysis using path analysis.

RESULTS: Patient experience affected patient satisfaction, hospital image affected patient satisfaction, patient experience did not directly influence patient loyalty, hospital image directly affected patient loyalty, and patient experience and hospital image indirectly affected loyalty patient through patient satisfaction. To the Meloy Public Hospital of Sangatta to maintain the good image of the hospital in providing services to the patient experience is memorable so that the desire arises to reuse hospital services in the future.

CONCLUSION: Based on research on the Influence of Patient Experience and Hospital Image on Patient Loyalty in Meloy Public Hospital of Sangatta, East Kutai Regency, researchers formulated the following conclusions: Patient experience influences patient satisfaction at the hospital. The image of the hospital has an effect on patient satisfaction at the hospital. Patient experience does not directly affect patient loyalty in the hospital. The image of the hospital has a direct effect on patient loyalty at the hospital. Patient experience and hospital image have an indirect effect on patient loyalty through patient satisfaction at the hospital.
\end{abstract}

\section{Introduction}

The hospital is a health service business, one of which is based on the principle of trust obtained from the patient's experience as well as from the hospital's image, so the problem of service quality, patient satisfaction that has an impact on patient loyalty is a very determining factor for its success. In the health sector, patient experience is an indicator in measuring service quality by placing patients at the center of service in hospitals [1].

Several other studies linking customer experience with loyalty, namely, Gentile [2] show that experience in identifying customer choices plays a fundamental role, and then influences purchasing decisions. Chang [3] show that experience is an important variable in understanding consumer behavior and repurchase. The results of the Biedenbach [4] study also showed that customer experience is directly proportional to brand loyalty.
East Kutai Regency has a number of public and special hospitals as well as government and private ownership, two regional public hospitals are in Sangatta with Class B and in Sangkulirang with Class D, three private public hospitals are located in Sangatta with Class $D$, and mother and child hospital is two located in Sangatta with Class C [5].

Based on preliminary data collection on three private public Class $D$ hospitals in Sangatta, East Kutai Regency, namely, Meloy Public Hospital, Medika Hospital, and Pupuk Kaltim Prima Sangatta Hospital regarding the number of inpatient visits in 2016-2018, namely, Meloy Public Hospital in the amount of 3037 (2016), 3220 (2017), and 2936 (2018). The number of inpatient visits to Medika Hospital is 75 (2016), 3838 (2017), and 4927 (2018). While the number of inpatient visits to Pupuk Kaltim Prima Hospital is 2307 (2016), 2304 (2017), and 4599 (2018) [6], [7], [8].

Based on the things mentioned above, there is a problem in the decrease in the number of inpatient 
visits at Meloy Public Hospital compared to Medika Hospital and Pupuk Kaltim Prima Hospital. This makes researchers interested in examining the problem of reducing the number of inpatient visits at Meloy Public Hospital.

Following are the results of inpatient satisfaction surveys at Meloy Public Hospital, in 2016 an average of $79.25 \%$ in patient satisfaction was obtained, in 2017 an average of $78.28 \%$ in patient satisfaction was obtained, while in 2018 it was obtained that the average inpatient satisfaction was $76.17 \%$ [6].

To measure the quality of services that are more meaningful then a measurement of patient experience is carried out. This is as stated by Jenkinson [9] that measuring patient experience provides a more meaningful indication of the quality of service received than measuring patient satisfaction.

Harrison [9] states that patient experience is the various interactions that patients have with the health-care system, including their care from the health plan, from doctors, nurses, and hospital staff, doctors' practices, and other health-care facilities.

Based on the survey data of inpatient satisfaction in the past 3 years at Meloy Public Hospital that was mentioned previously shows a decrease in patient satisfaction and overall inpatient satisfaction has not reached the standard $\geq 90 \%$ by ministry of health. This indicates that the quality of inpatient services at Meloy Public Hospital is not yet in line with hospital minimum service standards.

Based on the results of preliminary research show a decrease in the number of inpatient visits and a decrease in patient satisfaction and do not meet the standards of inpatient satisfaction according to hospital minimum service standards, an explanation from experts, the researchers are interested in conducting research on "The Influence of Patient Experiences and Hospital Image on Patient Loyalty at Meloy Public Hospital of Sangatta, East Kutai Regency with the aim of analyzing the influence of patient experience and hospital image on patient loyalty, as well as the influence of patient experience and hospital image on patient loyalty through patient satisfaction variables at Meloy Public Hospital of Sangatta, East Kutai Regency."

\section{Materials and Methods}

This research was conducted from May to July 2019 at Meloy Public Hospital of Sangatta. The type of research used was quantitative research, using Time Horizon One Shoot or Cross-Sectional.

The population in this study was all patients who did or had been hospitalized at Meloy Public Hospital of Sangatta regardless of sex. The sample of this study was 110 people. The sampling technique in this study was purposive sampling, where the sample was selected based on certain criteria which had been previously determined by the researcher before.

Data collection instruments in this study were questionnaires, regarding the independent variables in the form of patient experience and hospital image while the dependent variable was patient loyalty with patient satisfaction as a mediating variable.

Measurements used in data processing use a Likert scale, where respondents state the level of agreement or disagreement regarding various objects regarding the behavior of objects, people, or events. Likert scale is used to measure the attitudes, opinions, and perceptions of a person or group of people about social phenomena. In this study, respondents chose one of the available answers, and then the answers were given a specific score. Respondent's scores are then added up and this number is given a specific score.

The data analysis technique used is univariate analysis bivariate, multivariate analysis. Univariate analysis describes each variable used in the study and the characteristics of the respondents, namely, by looking at the description of the frequency distribution and the single percentage related to the research objectives. Bivariate analysis was carried out to find out the relationship between dependent and independent variables in the form of cross tabulation, to see the relationship between the independent and dependent variables. Multivariate analysis with path analysis is a technique for analyzing cause and effect relationships that occur in multiple regressions if the independent variables affect the dependent variable not only directly but also indirectly.

\section{Results}

Table 1 shows the correlation between patient experience and patient satisfaction obtained $p(0.000)$ $<0.05$ which means there is an influence between patient experience with patient satisfaction with a correlation of 0.631 which is in the category of strong correlation.

Table 1: Influence and relationship between research variables at Meloy Public Hospital in 2019

\begin{tabular}{llll}
\hline Variable & & $\mathrm{p}$ value & r value \\
\hline Patient experience & Patient satisfaction & $0.000^{*}$ & 0.631 \\
Hospital image & Patient satisfaction & $0.000^{*}$ & 0.610 \\
Patient experience & Patient loyalty & 0.146 & 0.139 \\
Hospital image & Patient loyalty & $0.000^{*}$ & 0.341 \\
Patient satisfaction & Patient loyalty & $0.000^{*}$ & 0.713 \\
\hline${ }^{*}$ Significant with $p<0.005$ & & &
\end{tabular}

Correlation between hospital image with patient satisfaction obtained $p(0.0)<0.05$ which means that there is an influence between hospital image with patient satisfaction with a correlation magnitude of 0.610 which is in the category of strong correlation. 
Correlation between patient experience and patient loyalty obtained $p(0.146)>0.05$ which means there is no influence between patient experiences with patient loyalty with a correlation of 0.139 which is in the very weak correlation category.

Correlation between hospital image and patient loyalty obtained $p(0.000)<0.05$ which means that there is an influence between hospital image with patient loyalty with a correlation of 0.341 which is in the weak correlation category.

Table 2 shows the total effect of the results of the path analysis, the results obtained total combination of hospital image variables on patient loyalty through patient satisfaction has the greatest weight value that is equal to 0.599 while the results of the combination of patient experience on patient loyalty through patient satisfaction has a weight value of 0.283 . This means that the patient's loyalty through the image of the hospital influences both directly and indirectly.

Table 2: Effect of total research variables at Meloy Public Hospital in 2019

\begin{tabular}{llll}
\hline Variable Combination & & Calculation & Result \\
\hline Patient experience $\rightarrow$ & $\begin{array}{l}\text { Patient loyalty through } \\
\text { patient satisfaction }\end{array}$ & $(0.223)+(0.060)$ & 0.283 \\
Hospital image $\rightarrow$ & $\begin{array}{l}\text { Patient loyalty through } \\
\text { patient satisfaction }\end{array}$ & $(0.338)+(0.261)$ & 0.599 \\
\hline
\end{tabular}

The results obtained in Table 3 that the frequency distribution of respondents based on the patient experience variable in the 2019 Meloy Public Hospital has a perception in the good category that is equal to $79.1 \%$. Respondents' perceptions of the hospital image are categorized as good at $85.5 \%$. Respondents' perceptions of patient satisfaction were categorized as satisfied, namely, $80.9 \%$. Respondents' perceptions of patient loyalty are categorized as loyal, which is $81.8 \%$.

Table 3: Frequency distribution of respondents based on research variables at Meloy Public Hospital in 2019

\begin{tabular}{lll}
\hline Research variable & Frequency $(\mathrm{n})$ & Percentage $(\%)$ \\
\hline Patient experience & & \\
$\quad$ a. Good & 87 & 79.1 \\
$\quad$ b. Poorly & 23 & 20.9 \\
Hospital image & & \\
$\quad$ a. Good & 94 & 85.5 \\
$\quad$ b. Poorly & 16 & 14.5 \\
Patient satisfaction & & \\
$\quad \begin{array}{l}\text { a. Satisfied } \\
\text { b. Less Satisfied }\end{array}$ & 89 & 80.9 \\
Patient loyalty & 21 & 19.1 \\
$\quad$ a. Loyal & & \\
$\quad$ b. Less Loyal & 90 & 81.8 \\
\hline
\end{tabular}

Based on the research that has been done, it is known that the characteristics of the respondents are seen in Table 4, the age of the respondents is mostly in the range of 26-35 years which is 30\%. Based on gender characteristics, most respondents were women with male distribution of $37.3 \%$ and women at $62.7 \%$. Based on the education level of the respondents, the most high school education is $70 \%$. Based on the respondent's profession, most private employees amounted to $65.5 \%$. Based on the income of the respondents, most of them earned $>$ Rp. 5,000,000 in the amount of $71.8 \%$. Based on the location of the respondent's residence, it is dominated in Sangatta City at $75.5 \%$. Based on the funding sources of respondents showed that the majority of respondents were covered by company guarantees/private insurance which is equal to $63.6 \%$ Based on the distance from the respondent's house to the hospital, with a distance of $\mathrm{km} 5 \mathrm{~km}$, it is equal to $69.1 \%$. Based on the length of treatment, showed in the majority of respondents, treated for 2 days amounted to $57.3 \%$. Based on the number of hospital visits, the majority of respondents were more than once, amounting to $85.5 \%$.

Table 4: Characteristics of respondents Meloy Public Hospital in 2019

\begin{tabular}{|c|c|c|}
\hline \multirow[t]{2}{*}{ Characteristics } & \multicolumn{2}{|c|}{ Frequency } \\
\hline & $\mathrm{n}$ & Percentage \\
\hline \multicolumn{3}{|l|}{ Age } \\
\hline $17-25$ & 24 & 21.8 \\
\hline $26-35$ & 33 & 30.0 \\
\hline $36-45$ & 17 & 15.5 \\
\hline $46-55$ & 14 & 12.7 \\
\hline $56-65$ & 13 & 11.8 \\
\hline$>65$ & 9 & 8.2 \\
\hline \multicolumn{3}{|l|}{ Gender } \\
\hline Male & 41 & 37.3 \\
\hline Female & 69 & 62.7 \\
\hline \multicolumn{3}{|l|}{ Education level } \\
\hline Senior High School & 77 & 70 \\
\hline Associate Degree & 23 & 20.9 \\
\hline Bachelor Degree & 10 & 9.1 \\
\hline \multicolumn{3}{|l|}{ Occupation } \\
\hline Jobless & 8 & 7.3 \\
\hline Private Employee & 72 & 65.5 \\
\hline Civil Servant & 13 & 11.8 \\
\hline Student/University Student & 10 & 9.1 \\
\hline Entrepreneur & 7 & 6.4 \\
\hline \multicolumn{3}{|l|}{ Income } \\
\hline No Income & 18 & 16.4 \\
\hline Rp 1.500.000 - Rp 2.000.000 & 0 & 0 \\
\hline Rp 2.000.000 - Rp 2.500.000 & 0 & 0 \\
\hline Rp 2.500 .000 - Rp 5.000 .000 & 13 & 11.8 \\
\hline$>\operatorname{Rp} 5.000 .000$ & 79 & 71.8 \\
\hline \multicolumn{3}{|l|}{ Residence Location } \\
\hline In Sangatta & 83 & 75.5 \\
\hline Out of the city of Sangatta & 27 & 24.5 \\
\hline \multicolumn{3}{|l|}{ Funding Source } \\
\hline Direct Cost & 14 & 12.7 \\
\hline Independent National Health Insurance & 18 & 16.4 \\
\hline Dependent National Health Insurance & 8 & 7.3 \\
\hline Company Guarantees/Private Health Insurance & 70 & 63.6 \\
\hline \multicolumn{3}{|l|}{ Distance from Home to Hospital } \\
\hline$<5 \mathrm{~km}$ & 76 & 69.1 \\
\hline$>5 \mathrm{~km}$ & 43 & 30.9 \\
\hline \multicolumn{3}{|l|}{ Duration of treatment } \\
\hline 1 day & 31 & 28.2 \\
\hline 2 days & 63 & 57.3 \\
\hline$>2$ days & 16 & 14.5 \\
\hline \multicolumn{3}{|l|}{ Number of visit to the hospital } \\
\hline The first time & 16 & 14.5 \\
\hline$>1$ times & 94 & 85.5 \\
\hline
\end{tabular}

\section{Discussion}

Based on the results of the study showed that patient experience has a positive and significant influence on patient satisfaction. This is in line with research conducted by Kumah [11] saying that patient experience and patient satisfaction are interrelated in assessing the quality of health services, interconnected but in different concepts. The patient experience is about managing sudden changes between emotional and physical patients while undergoing health-care procedures and maximizing the patient's social, mental, physical, and fit health. To support this effort it 
is recommended to personalize treatment, partner with patients, and empowerment of employees [12].

Based on the results of the research showed that the image of the hospital has a positive and significant influence on patient satisfaction. The results of this research are consistent with research conducted by $\mathrm{Wu}$ [13] who found that the image of the hospital significantly affected satisfaction. This means that the better the hospital's image, the higher the satisfaction felt by patients at Meloy Public Hospital of Sangatta. The results of this research are consistent with the opinions expressed by Andreassen [14] stating that images influence customer satisfaction. Brand image is always associated with product/service attributes because to provide satisfaction to consumers and consumers react to the product//service attributes they buy [15].

Based on the results of the research showed that patient experience has a negative and not significant effect on patient loyalty. The results of this research are not in line with the results of Prasojo's research [16] entitled Analysis of Loyalty Determination of Inpatients in Dr. Moewardi in Surakarta. The results of the research stated that there was a significant relationship between the Determinant Analysis of Loyalty of Inpatients at RSUD Dr. Moewardi in Surakarta.

Based on the results of the research showed that the image of the hospital has a positive and significant influence on patient loyalty. According to Aaker and Keller in Fatmawati [17] stated that the hospital image is the patient perception of quality related to the brand or company name. The results of this research are in line with the results of research conducted by Hidajahningtyas [18] with the research title "Influence of Image, Service Quality and Satisfaction on Patient Loyalty of Executive Polyclinics Regional Hospital Dr. Soebandi Jember Regency." In this research concluded that the higher the level of brand image that plays an important role in changing the quality of service and patient satisfaction, it will make patient loyalty even higher. The image of the hospital is proven to have a significant effect on customer loyalty. The results of this study support the theory that consumer loyalty is formed from the image that exists in a product or service from a company's brand [19].

Based on the results of the study indicate that the patient experience indirectly influences patient loyalty through patient satisfaction, as well as the image of the hospital, stating that there is an indirect effect between the influence of the hospital's image on patient loyalty through patient satisfaction significantly. Research Mittal [20] revealed that loyalty will increase rapidly after passing satisfaction within a certain threshold, there is an increase in scale returns in a reciprocal relationship between the two. The results of this study are consistent with research conducted by Lam [21] revealing patient satisfaction and loyalty having reciprocal relationships with each other. Other research supporting the relationship of satisfaction and loyalty was stated by Gronholdt [22] that customer satisfaction has a positive effect (strong significance) in the formation of loyalty. In addition, Kessler [23] show a statistically significant influence between satisfaction and loyalty, although the effect of overall patient satisfaction tends to be relatively small. The same was stated by Haryeni [24] the effect of satisfaction shows a positive relationship on loyalty [25], [26], [27].

\section{Recommendation}

Based on the results of the research and conclusions that have been formulated, then put forward some suggestions or recommendations to maintain the factors that affect patient experience, the image of the hospital for the achievement of patient satisfaction which has implications for patient loyalty.

\section{References}

1. Luxford $\mathrm{KL}$, Sutton $\mathrm{S}$. How does patient experience fit into the overall healthcare picture? Patient Exp J. 2014;1(1):20-7.

2. Gentile C, Spiller N, Noci G. How to sustain the customer experience: An overview of experience components that co-create value with the customer. Eur Manag J. 2007;25(5):395410. https://doi.org/10.1016/j.emj.2007.08.005

3. Chang $\mathrm{HH}$, Chen SW. The impact of online store environment cues on purchase intentions: Trust and perceived risk as a mediator. Online Inf Rev. 2008;32(6):818-41. https://doi. org/10.1108/14684520810923953

4. Biedenbach $G$, Marell A. The impact of customer experience on brand equity in business to business service setting. J Brand Manag. 2010;17(6):446-58. https://doi.org/10.1057/bm.2009.37

5. Direktorat Jenderal Pelayanan Kesehatan, Data. Available from: http://www.sirs.yankes.kemkes.go.id/rsonline/report. [Last accessed on 2019 Apr 20].

6. Sangatta RS. Laporan Tahun 2018. Sangatta: Rekam Medis Rumah Sakit Umum Meloy Sangatta; 2018.

7. Medika RS. Laporan Tahun 2018. Sangatta: Rekam Medis Rumah Sakit Medika; 2018. https://doi.org/10.33560/.v6i2.189

8. Prima RS. Laporan Tahun 2018. Sangatta: Rekam Medis Rumah Sakit Pupuk Kaltim Prima; 2018.

9. Jenkinson C, Coulter A, Bruster S, Richards N, Chandola T. Patients experiences and satisfaction with health care: Results of a questionnaire study of specific aspects of care. Qual Saf Health Care. 2002;11(4):335-9. https://doi.org/10.1136/ qhc.11.4.335

PMid:12468693

10. Harrison N, Agnew S, Serido J. Attitudes to debt among indebted undergraduates: A cross-national exploratory factor analysis. J Econ Psychol. 2015;46:62-73. https://doi.org/10.1016/j. joep.2014.11.005

11. Kumah E, Kesse FO, Anaba C. Understanding and using patient experience feedback to improve health care quality: Systematic review and framework development. J Patient Cent Res Rev. 2017;4(1):24-31. https://doi.org/10.17294/2330-0698.1416 PMid:31413967

12. Needham BR. The truth about patient experience: What we can learn from other industries, and how three ps can 
improve health outcomes, strengthen brands, and delight customers. J Healthc Manag. 2012;57(4):255-63. https://doi. org/10.1097/00115514-201207000-00006 PMid:22905604

13. Wu C. The impact of hospital brand image on servive quality, patient satisfaction and loyalty. J Bus Manag. 2011;5(12):4873-82.

14. Andreassen TW, Lindestad B. Customer loyalty and complex service: The impact of corporate image on quality, customer satisfaction and loyalty for coustomers with varrying degrees of service expertise. Int J Serv Ind Manag 1998;9(1):7-13. https:// doi.org/10.1108/09564239810199923

15. Nugroho FY. Pengaruh citra merek dan kepuasaan pelanggan terhadap loyalitas pelanggan. J Manag Pemasaran. 2011;2(2):90-102. https://doi.org/10.31294/jp.v17i1.5206

16. Prasojo SB. Analisis Determinan Loyalitas Pasien Rawat Inap RSUD Dr. Moewardi di Surakarta (Skripsi). Surakarta: Universitas Sebelas Maret; 2013. https://doi.org/10.26911/ theicph.2019.05.34

17. Fatmawati I. Citra Rumah Sakit, Kepuasan dan Loyalitas Pelanggan: Studi Pada Rumah Sakit PKU Muhammadiyah Yogyakarta. Utilitas. 2004;12:23-33. https://doi.org/10.31000/ jmb.v8i2.1604

18. Hidajahningtyas N, Sularso A, Suroso I. Pengaruh citra, kualitas layanan dan kepuasan terhadap loyalitas pasien di poliklinik eksekutif rumah sakit daerah Dr. Soebandi Kabupaten Jember. JEAM. 2013;12(1):39-53. https://doi.org/10.25047/jii.v16i2.291

19. dan Maylina WH. Faktor-faktor yang mempengaruhi kesetiaan terhadap merek pada konsumen pasta gigi pepsodent di surabaya. Ventura. 2003;6(1):98-115. https://doi.org/10.35870/ emt.v3i2.112
20. Mittal V, Kamakura WA. Satisfaction, repurchase intent, and repurchase behavior: Investigating the moderating effect of customer characteristics. J Market Res. 2001;38:131-42. https:// doi.org/10.1509/jmkr.38.1.131.18832

21. Lam SY, Shankar V, Erramilli MK, Murthy B. Customer value, satisfaction loyalty, and switching costs; an illustration from a business to business service context. J Acad Market Sci.2004;32:293-311.https://doi.org/10.1177/0092070304263330

22. Gronholdt L, Martensen A, Kristensen K. The relationship between customer satisfaction and loyalty: Cross-industry differences. Total Qual Manag. 2000;11(4-6):509-14. https://doi. org/10.1080/09544120050007823

23. Kessler DP, Mylod D. Does patient satisfaction affect patient loyalty? Int J Health Care Qual Assur. 2009;24(4):266-73. https://doi.org/10.1108/09526861111125570

24. dan Yendra $\mathrm{NH}$. Kualitas layanan, kepuasan dan loyalitas pasien pada rumah sakit swasta di kota padang: Berpikir ke masa depan. MENARA IImu. 2019;13(1):87-96. https://doi. org/10.9744/jmk.13.1.32-39

25. Muhith A, Winarti E, Perdana SS, Haryuni S, Rahayu KI, Mallongi A. Internal locus of control as a driving factor of early detaction behavior of servical cancer by inspection visual of acetic acid method. Open Access Maced J Med Sci. 2020;8(E):113-6. https://doi.org/10.3889/oamjms.2020.4341

26. Mallongi A, Birawida AB, Astuti RD, Saleh M. Effect of lead and cadmium to blood pressure on communities along coastal areas of Makassar, Indonesia. Enferm Clín. 2020;30(4):313-7. https:// doi.org/10.1016/j.enfcli.2020.03.001

27. Astuti HJ, Nagase K. Patient loyalty to healthcare organizations: Relationship marketing and satisfaction. Int J Manag Market Res. 2014;7(2):39-56.

\section{Author Queries???}

AQ6: Kindly cite reference 10 in the text part and also chronological order 